

\title{
Total Synthesis of the Isoketal 5-D 2 -IsoK Natural Product Based on Organocatalysis
}

\author{
Mathieu Candy, Thierry Durand, Jean-Marie Galano, Camille Oger
}

\section{To cite this version:}

Mathieu Candy, Thierry Durand, Jean-Marie Galano, Camille Oger. Total Synthesis of the Isoketal 5-D 2 -IsoK Natural Product Based on Organocatalysis. European Journal of Organic Chemistry, 2016, 10.1002/ejoc.201601301 . hal-02593367

\section{HAL Id: hal-02593367 https://hal.science/hal-02593367}

Submitted on 15 May 2020

HAL is a multi-disciplinary open access archive for the deposit and dissemination of scientific research documents, whether they are published or not. The documents may come from teaching and research institutions in France or abroad, or from public or private research centers.
L'archive ouverte pluridisciplinaire HAL, est destinée au dépôt et à la diffusion de documents scientifiques de niveau recherche, publiés ou non, émanant des établissements d'enseignement et de recherche français ou étrangers, des laboratoires publics ou privés. 


\title{
Total Synthesis of the Isoketal 5- $D_{2}$-IsoK Natural Product Based on Organocatalysis
}

\author{
Mathieu Candy, ${ }^{[a]}$ Thierry Durand, ${ }^{[a]}$ Jean-Marie Galano, ${ }^{*[a]}$ and Camille Oger*[a]
}

Abstract: The enantioselective total synthesis of the highly reactive isoketal $5-\mathrm{D}_{2}$-IsoK was accomplished. The synthesis involved construction of the isoketal core by an organocatalyzed Michael addition between ideally functionalized aldehyde and nitroolefin partners with good enantioselectivity. The lateral chains were branched through Horner-Wadsworth-Emmons and Wittig olefinations to provide flexibility, whereas the final deprotection and oxidation steps were performed under mild conditions to avoid known racemization and/or degradation of the very sensitive isoketal.

\section{Introduction}

Isoprostanes (IsoPs) are prostaglandin-like compounds discovered in the 1990s as oxidative-stress-induced nonenzymatic peroxidation products of arachidonic acid (C20:4 n-6). ${ }^{[1]}$ They are formed in the human body from phospholipids through bicyclic endoperoxide intermediates (G-IsoPs), and they can be partially or completely reduced to produce the well-known D-, E- or F-types of IsoPs (Scheme 1). ${ }^{[2]}$ The same endoperoxides may also undergo rearrangement in vivo to produce isoketal derivatives (IsoKs), also called isolevuglandins. ${ }^{[3]}$ IsoKs react with the primary amine groups of proteins (lysine residues) or phosphatidylethanolamine to form the corresponding pyrroles, which are readily oxidized over time into highly stable lactam and hydroxylactam adducts. ${ }^{[4]}$ Much more than just a dosimeter of oxidative stress, ${ }^{[5]}$ IsoKs appear to be disease biomarkers in pathological processes, as exogenous IsoKs on cultured cells include induction of inflammatory pathways, immune responses, and cell death, as well as the inhibition of ion-channel function. ${ }^{[6]}$

From a structural point of view, IsoKs possess two aliphatic side chains containing two double bonds ( $E$ and $Z$ ), fixed onto a methyl $\gamma$-keto aldehyde. However, despite their relatively simple chemical structures, this class of compounds represents a challenging target for the synthetic community. First, endoperoxide rearrangements could give rise to the $E$ and $D$ isomers that bear three stereogenic centers, which would result in 64 possible IsoK isomers. Second, the construction of the highly reactive $\gamma$ keto aldehyde motif is not a trivial task, as the C8 and C12 stereogenic centers can readily racemize under acidic or basic conditions; third, the $\beta, \gamma$-unsaturated aldehyde may easily

[a] Institut des Biomolécules Max Mousseron (IBMM), UMR 5247 CNRS, Université de Montpellier, ENSCM Faculté de Pharmacie,

15 avenue Charles Flahault, BP 14491, 34093 Montpellier cedex 05, France E-mail: jean-marie.galano@umontpellier.fr camille.oger@umontpellier.fr

https://ibmm.umontpellier.fr/?-Synthese-de-Lipides-Bioactifs-

Supporting information and $O R C I D(s)$ from the author(s) for this article are

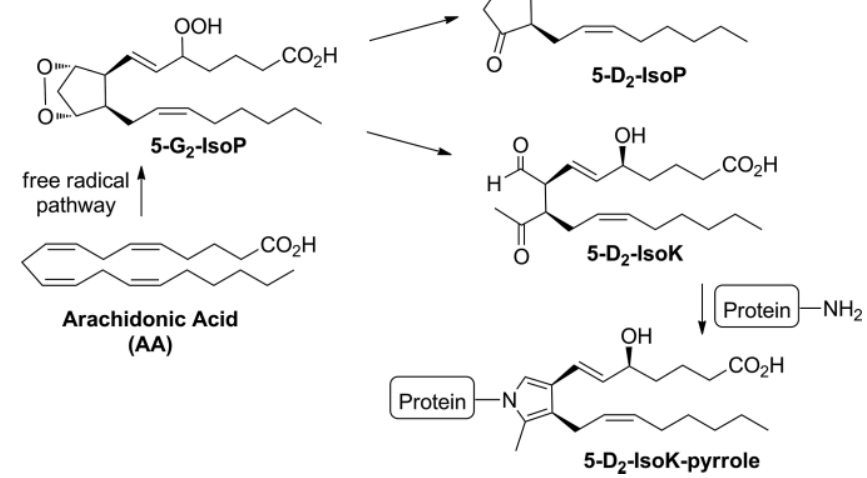

Scheme 1. Biosynthesis of IsoKs and pyrrole derivatives.

go through conjugation or conjugation/dehydration of the hydroxy group at $\mathrm{C} 5$.

To the best of our knowledge, only the group of Salomon has attempted this synthetic challenge. More particularly, they reported the synthesis and biological investigations of two IsoK derivatives, namely, $5-D_{2}-$ IsoK and $12-E_{2}-I$ soK, and $17-E_{4}-$ NeuroK derived from docosahexaenoic acid. ${ }^{[7]}$ The key features of their synthetic route include: (1) diastereoselective 1,4-addition of an elaborated vinylcyanocuprate to a chiral $\gamma$-alkoxyenone to build the central core; (2) deprotection of the sensitive aldehyde function (protected as acetonide) in the last step under acidic conditions $\left(\mathrm{AcOH}, \mathrm{H}_{2} \mathrm{O}\right)$ followed by mild oxidative cleavage of a vicinal diol. However, this elegant strategy has some disadvantages that limits its practicality, such as the low control of the stereochemical outcome of the 1,4-addition (d.r. 1.5:1), combined with epimerization of the acidic centers next to the keto and aldehyde functionalities.

Our interest in lipid peroxidation prompted us to develop a new strategy allowing the synthesis of IsoK derivatives by taking into account the inherent epimerization problems and also a more flexible approach for introduction of the side chains. Herein, we report our efforts in the enantioselective synthesis 
of $5-\mathrm{D}_{2}$-IsoK ( 1 ) by using an organocatalyzed Michael addition between a nitroolefin and an aldehyde as a key step.

\section{Results and Discussion}

Scheme 2 reveals the essential features of our retrosynthetic disconnections. First, we planned to uncover the sensitive aldehyde function of $5-\mathrm{D}_{2}$-IsoK (1) in the last stage under mild conditions for dimethyl acetal hydrolysis of compound 4 . More classical and, therefore, versatile introduction of the two lateral chains would proceed through Wittig and Horner-WadsworthEmmons (HWE) olefinations from 5. Interconversion of the triethylsiloxy (OTES) and OAc groups of $\mathbf{5}$ by Nef reaction and simple methyl alkylation would reveal intermediate 6, which could be obtained through an organocatalyzed Michael addition between simple aldehyde $\mathbf{8}$ and nitroolefin $\mathbf{7}$.

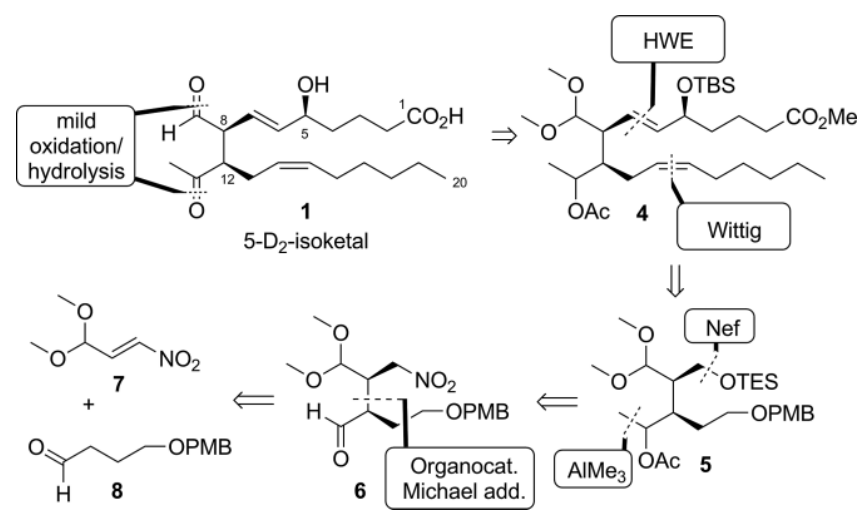

Scheme 2. Retrosynthetic approach.

Synthesis of common skeleton $\mathbf{5}$ of all possible types of IsoKs started with the organocatalytic Michael addition (Scheme 3) of aldehyde $\mathbf{8}^{[8]}$ and nitroolefin 7 (1.15:1 ratio aldehyde/olefin) by using Jørgensen-Hayashi's catalyst 9 (5 mol-\%) and p-nitrophenol as a co-catalyst (10 mol-\%), which afforded the expected 1,4-nitroaldehyde in excellent yield (97\%) with good enantiomeric excess $(90 \%)$ and diastereomeric ratio $(3: 1 d r)$, clearly in the range of that previously report by Ruiz et al. ${ }^{[9]}$ The C10 methyl group was then introduced by mild alkylation of aldehydes $\mathbf{6 a} \mathbf{a} \mathbf{6} \mathbf{b}$ by using trimethylaluminum, avoiding epimerization of the base-sensitive aldehyde. The resulting nitro compound was subjected to the Nef reaction, ${ }^{[10]}$ which proved to be delicate and unsuccessful following standard protocols. The milder conditions developed by McMurry ${ }^{[11]}$ also led to degradation of the expected aldehyde. Finally, the use of sodium nitrite and acetic acid as reported by Mioskowski's group proceed smoothly. ${ }^{[12]}$ These reaction conditions known to convert primary nitro groups into carboxylic acids led, in our case, to lactone cis/trans-10 in $64 \%$ yield (over two steps) as a mixture of four diastereoisomers, probably through intermolecular trapping of the known nitrile oxide intermediate formed. ${ }^{[13]}$ Gratifyingly, treatment of the mixture of cis/trans-10 with a catalytic amount of 1,8-diazabicyclo[5.4.0]undec-7-ene (DBU) induced full epimerization of cis-lactone $\mathbf{1 0}$ into the thermodynamically more stable and desired trans-lactone 10. By this way, the unwanted diastereoisomer could be easily converted into the desired one. This strategy fully overcame the low diastereoselectivity of the first Michael addition, thus avoiding loss of material. Next, trans-lactone $\mathbf{1 0}$ was reduced with lithium aluminum hydride to the corresponding diol prior to selective protection of the primary alcohol as a triethylsilyl ether and secondary hydroxy group as its acetate to furnish intermediate $\mathbf{5}$ in excellent yield ( $81 \%$ yield over four steps) and a unique purification step. At that stage, flash column chromatography allowed the separation of the two $\mathrm{C} 11$ diastereomers of $\mathbf{5}$, which was not necessary for completion of the synthesis but quite handy. Therefore, the synthesis proceeded with the major diastereomer
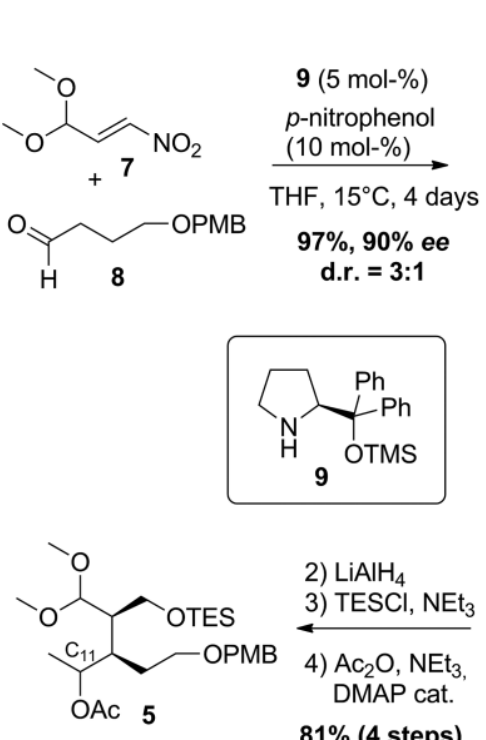

2) $\mathrm{LiAlH}_{4}$ 3) $\mathrm{TESCl} \mathrm{NEt}_{3}$

4) $\mathrm{Ac}_{2} \mathrm{O}, \mathrm{NEt}_{3}$ DMAP cat. $81 \%$ (4 steps)

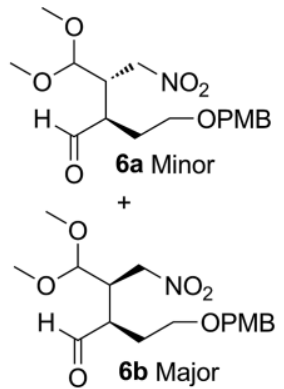

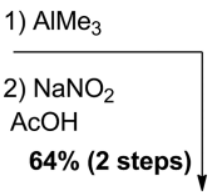<smiles>COCCC1C(OC)C(=O)O[C@H]1C</smiles><smiles>COC(OC)[C@H]1C(=O)O[C@H](C)[C@@H]1CCO[Mg]</smiles>
cis and trans 
of compound $\mathbf{5}$ (configuration of $\mathrm{C} 11$ not determined), for NMR spectroscopy simplification and attribution of the absolute configuration of the allylic alcohol that remained to be introduced.

With requisite intermediate $\mathbf{5}$ in hand, we next focused on the construction of the lateral chains (Scheme 4). Exposing TESprotected primary alcohol $\mathbf{5}$ to Swern conditions cleanly furnished, without purification, the corresponding aldehyde. The $\alpha$-chain (bearing the acid moiety) was then introduced by using HWE olefination with phosphonate $\mathbf{1 1}^{[14]}$ and barium hydroxide as base to prevent epimerization at $\mathrm{C} 8{ }^{[15]}$ and desired ester 12 was obtained in $78 \%$ yield. Luche reduction of the $\alpha, \beta$ unsaturated ketone gave a 3:1 diastereomeric mixture of the corresponding allylic alcohols in $98 \%$ yield. The C5 epimers were separated by column chromatography, and the configuration of the major epimer was unambiguously attributed as (5S) by NMR spectroscopy analysis of the corresponding mandelate derivatives. ${ }^{[16]}$ The $\omega$-chain was introduced from the (5S) diastereoisomer by protection as tert-butyldimethylsilyl (TBS) ether 13 prior to cleavage of the $p$-methoxybenzyl (PMB) ether by using 2,3-dichloro-5,6-dicyanobenzo-1,4-quinone (DDQ) to release the primary alcohol. Dess-Martin periodinane (DMP) oxidation and Wittig olefination by using phosphonium salt 14 and sodium hexamethyldisilazane (NaHMDS) as a base furnished desired $(E, Z)$-diene $\mathbf{4}$ in $71 \%$ yield over three steps.

Having succeeded in the stereoselective installation of the olefin lateral chains, we next conducted compound $\mathbf{4}$ through<smiles>COCCC(C(C)OC(C)=O)C(CCOC(C)=O)C(OC)OC</smiles>

1) Swern

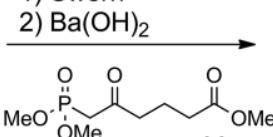

1

$78 \%$ (2 steps)<smiles>COCCC(C(OC)OC(C)=O)C(C=CC(=O)CCCC(=O)OC)C(OC)OC</smiles>

1) $\mathrm{NaBH}_{4}, \mathrm{CeCl}_{3}$

$98 \%$, d.r. $=3: 1$

2) TBSCl, Imidazole<smiles>CCCCC/C=C\C[C@H](/C=C/[C@H](CCCC(=O)OC)[C@@H](OC)C(C)OC(C)=O)C(OC)OC</smiles>

1) $\mathrm{DDQ}$

2) DMP

3) NaHMDS

$\stackrel{\oplus}{\oplus{ }^{\ominus}}$

14

$90 \%$

$71 \%$ (3 steps)<smiles></smiles>

Scheme 4. Introduction of the lateral chains.<smiles>CCCCCCCC(C=CC(C(CCCC(=O)OC)OC)C(OC)OC)C(C)OC(C)=O</smiles>

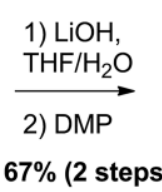<smiles>CCCCC/C=C\C[C@H](/C=C/[C@H](CCCC(=O)O)[C@@H](CCCC)OC)C(OC)OC</smiles><smiles>CCCCCCCC(=O)O[Mg]</smiles>

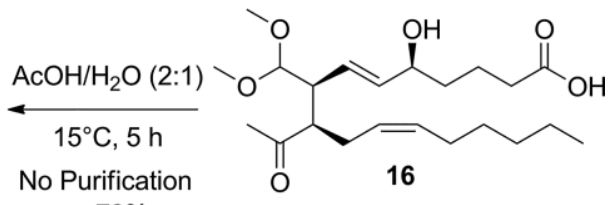
$79 \%$<smiles>[3H][R6]O[Na]</smiles><smiles>CCCCC/C=C/CC(C/C=C/CCCC(=O)O)C(C)=O</smiles> 
deprotection and oxidation steps to achieve the synthesis of desired $5-D_{2}$-IsoK (1, Scheme 5). The ester and acetate functions were simultaneously cleaved by using lithium hydroxide, but whereas the methyl ester reacted rapidly, the acetate group was found to be surprisingly more stable and 5 days was required to achieve full cleavage. Notably, the classical use of potassium carbonate in methanol was totally ineffective to remove the acetate group. The resulting secondary alcohol was readily oxidized by using Dess-Martin periodinane to give ketone $\mathbf{1 5}$ in $67 \%$ yield over two steps. At that stage, our plan was to convert intermediate $\mathbf{1 5}$ into isoketal $\mathbf{1}$ by concomitant acidic deprotection of both the TBS ether and dimethyl acetal groups. Despite our efforts, under all conditions tested (Amberlyst 15, $\mathrm{BiBr}_{3}, \mathrm{AcOH} / \mathrm{H}_{2} \mathrm{O}$ ) elimination product $\mathbf{1 8}$ was formed in a large amount along with desired product 1 and other undetermined byproducts. We thus decided to remove the TBS group, as corresponding alcohol $\mathbf{1 6}$ would be less prompt to elimination. The use of a large excess amount of tetrabutylammonium fluoride (TBAF) buffered with ammonium chloride ${ }^{[17]}$ afforded alcohol 16 in $46 \%$ yield (81\% based on recovered starting material) without epimerization at $\mathrm{C} 12$ and a trace amount of a lactonization product (separable if desired). Only one step from the desired and sensitive IsoK, we had further problems to deal with, as the right balance between conversion into 1, minimum formation of lactone $\mathbf{1 7}$, and elimination product $\mathbf{1 8}$, in addition to other potential double epimerization. Furthermore, target 1 was not suitable for silica gel purification. Finally, subjecting acetal 16 to a mixture of acetic acid and water at $15^{\circ} \mathrm{C}$ for $5 \mathrm{~h}$ gave the best possible outcome by avoiding any purification and limiting the formation of side products. As a result, $5-\mathrm{D}_{2}-$ IsoK (1) was thus obtained in $79 \%$ yield reproducibly with up to $10-20 \%$ of lactonization product 17 and $5-10 \%$ of compound 18. However, despite this fact, the purity of IsoK $\mathbf{1}$ is significantly improved relative to that of the first synthesis reported. ${ }^{[7 b]}$ Finally, because IsoK $\mathbf{1}$ is a bioactive compound of high interest but clearly quite unstable, we decided to provide a sub-micromolar scale access to IsoK $\mathbf{1}$ from a storable solution of compound 16. ${ }^{[18]}$ Thus, simple treatment of a methanol solution of 16 with acetic acid and water at $15{ }^{\circ} \mathrm{C}$ provided desired compound $\mathbf{1}$ in good purity suitable for direct biological use.

\section{Conclusion}

In conclusion, we achieved a novel enantioselective synthesis of $5-D_{2}$-isoketal $\left(1,5-D_{2}\right.$-IsoK) by using a unified strategy for the construction of the isoketal core. Multigram access to core intermediate 5, easiness of side-chain introduction, and a last step deprotection sequence may be employed for the synthesis of other polyunsaturated fatty acid isoketal derivatives. Furthermore, a sub-micromolar scale for the last step of the synthesis of 1 was described. This represents easy access to reliable quantities of highly reactive 1 suitable for biological applications.

Supporting Information (see footnote on the first page of this article): Full details of experimental procedures, characterization data, and NMR spectra.

\section{Acknowledgments}

We gratefully thank the University of Montpellier (M.C. postdoctoral fellowship), the Centre National de la Recherche Scientifique (CNRS), and Dr. Stellios Arseniyadis (ESPCl ParisTech, France) for measuring the enantiomeric excess values by chiral super fluidic chromatography.

Keywords: Fatty acids · Isoketals · Olefination .

Organocatalysis - Total synthesis

[1] J. D. Morrow, K. E. Hill, R. F. Burk, T. M. Nammour, K. F. Badr, L. J. Roberts II, Proc. Natl. Acad. Sci. USA 1990, 87, 9383-9387.

[2] For a review, see: U. Jahn, J.-M. Galano, T. Durand, Angew. Chem. Int. Ed. 2008, 47, 5894-5955; Angew. Chem. 2008, 120, 5978-6041.

[3] For reviews, see: a) L. J. Roberts II, J. D. Morrow, Cell. Mol. Life Sci. 2002, 59, 808-820; b) S. S. Davies, V. Amarnath, L. J. Roberts II, Chem. Phys. Lipids 2004, 128, 85-99; c) M. Zhang, W. Li, T. Li, Molecules 2011, 16, 5333-5348.

[4] C. J. Brame, R. G. Salomon, J. D. Morrow, L. J. Roberts II, J. Biol. Chem. 1999, 274, 13139-13146.

[5] S. S. Davies, V. Amarnath, K. S. Montine, N. Bernoud-Hubac, O. Boutaud, T. J. Montine, L. J. Roberts II, FASEB J. 2002, 16, 715-717.

[6] R. G. Salomon, W. Bi, Antioxid. Redox Signaling 2015, 22, 1703-1718.

[7] a) G. Subbanagounder, R. G. Salomon, K. K. Murthi, C. Brahme, L. J. Roberts II, J. Org. Chem. 1997, 62, 7658-1766; b) S. C. Roy, L. Nagarajan, R. G. Salomon, J. Org. Chem. 1999, 64, 1218-1224; c) W. Sha, R. G. Salomon, J. Org. Chem. 2000, 65, 5315-5326.

[8] a) S. P. Chavan, K. R. Harale, Tetrahedron Lett. 2012, 53, 4683-4686; b) J. Franzén, M. Marigo, D. Fielenbach, T. C. Wabnitz, A. Kjærsgaard, K. A. Jørgensen, J. Am. Chem. Soc. 2005, 127, 18296-18304; c) Y. Hayashi, H. Gotoh, T. Hayashi, M. Shoji, Angew. Chem. Int. Ed. 2005, 44, 4212-4215; Angew. Chem. 2005, 117, 4284-4287.

[9] N. Ruiz, E. Reyes, J. L. Vicario, D. Badía, L. Carrillo, U. Uria, Chem. Eur. J. 2008, 14, 9357-9367.

[10] For a review, see: R. Ballini, M. Petrini, Tetrahedron 2004, 60, 1017-1047.

[11] a) J. E. McMurry, J. Melton, J. Org. Chem. 1973, 38, 4367-4373; b) J. E. McMurry, Acc. Chem. Res. 1974, 7, 281-286.

[12] C. Matt, A. Wagner, C. Mioskowski, J. Org. Chem. 1997, 62, 234-235.

[13] C. Palomo, S. Vera, A. Mielgo, E. Gómez-Bengoa, Angew. Chem. Int. Ed. 2006, 45, 5984-5987; Angew. Chem. 2006, 118, 6130-6133.

[14] I. Delamarche, P. Mosset, J. Org. Chem. 1994, 59, 5453-5457.

[15] I. Paterson, K.-S. Yeung, J. B. Smaill, Synlett 1993, 774-776.

[16] a) J. M. Seco, E. Quiñoá, R. Riguera, Tetrahedron: Asymmetry 2001, 12, 2915-2925; b) I. Chataigner, J. Lebreton, D. Durand, A. Guingant, J. Villiéras, Tetrahedron Lett. 1998, 39, 1759-1762.

[17] a) D. F. Taber, K. Kanai, Tetrahedron 1998, 54, 11767-11782; b) D. F. Taber, H. Yu, C. D. Incarvito, A. L. Rheingold, J. Am. Chem. Soc. 1998, 120, 1328513290.

[18] See the Supporting Information. 